\title{
Uma Crítica a Três Certezas Juspositivistas e a Busca de Outro Paradigma Hermenêutico
}

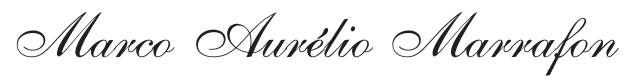

Mestrando em Direito do Estado pela UFPR.

\section{SUMÁRIO}

Introdução;

I - A primeira certeza: o dogma da onipotência do legislador;

II - A segunda certeza: a segurança positivista e o mito da neutralidade do juiz;

III - A terceira certeza: a hermenêutica de cunho empirista positivista;

$I V$ - O rompimento com as idéias positivistas através da busca da instrumentalidade das normas;

Referências bibliográficas.

\section{Introdução}

$\mathbf{E}$

m HOBBES, vê-se que o fortalecimento e a consolidação do Estado Absolutista dependia de um direito que atuasse imperativamente, como um comando, pois seu objetivo último era garantir a segurança antes inexistente no estado de barbárie. Por isso, esse modelo estatal concebia o direito em função de seu elemento de coação e reconhecia apenas a emanação jurídica proveniente do próprio Estado, adotando, de maneira sistemática, a concepção monista de direito e lançando as bases do positivismo jurídico.

Posteriormente, com a ascensão da burguesia ao poder e o aprimoramento da escola positivista, continuava sendo interessante a adoção dessa concepção pois a burguesia necessitava de um instrumento de coação e de legitimação para que se perenizasse no poder.

Para tanto, consagrou-se na teoria positivista do direito o dogma da onipotência do legislador e, junto a ele, os princípios 
da neutralidade e imparcialidade do juiz, sendo que, no momento de aplicação da norma geral ao caso concreto, o jurista deveria buscar a vontade do legislador (corrente subjetivista) ou a vontade da lei (corrente objetivista), através de uma teoria hermenêutica que buscasse o sentido original das normas, numa relação entre o sujeito cognoscente, o objeto de análise e a linguagem como um terceiro elemento interposto entre eles.

Nesse artigo, buscar-se-á compor uma análise crítica dessas três certezas fundamentais à teoria juspositivista, demonstrando seus elementos que ocultam a realidade, deixando livre de responsabilidade os operadores do direito que trabalham na resolução do conflito jurídico sem preocupações com o conflito social a ele subjacente, bem como o papel da hermenêutica tradicional, nos moldes descritos no parágrafo anterior.

\section{I - A primeira certeza: o dogma da onipotência do legislador}

No âmbito das relações entre o juiz e o legislador, surge o dogma da onipotência do legislador como o princípio que norteia toda a teoria positivista, primeiramente em HOBBES, que o analisava sob uma ótica absolutista e posteriormente em MONTESQUIEU, através de uma ótica liberal, justificando, assim, a monopolização jurídica por parte do Estado e evitando que juízes viessem a criar direito (ou direitos) que fugissem da órbita de controle do próprio Estado.

\section{No dizer de NORBERTO BOBBIO} esse dogma "elimina os poderes intermediários e atribui um poder pleno, exclusivo e ilimitado ao legislador, que é o aspecto absolutista. Mas tal eliminação dos poderes intermediários possui também um aspecto liberal, porque garante o cidadão contra as arbitrariedades de tais poderes: a liberdade do juiz de pôr as normas, extraindo-as de seu próprio senso de eqüidade ou da vida social, pode dar as arbitrariedades nos confrontos entre cidadãos, enquanto que o legislador, pondo normas iguais para todos, representa um impedimento para a arbitrariedade do poder judiciário". ${ }^{1}$

Todavia, mesmo levando em consideração o regime mais democrático possível, o legislador contempla a vontade da classe que está no poder (até porque ele também faz parte dela) em detrimento da vontade do povo, e exatamente aí se encontra outra vantagem para aqueles que necessitam manter o status quo em adotar incondicionalmente a teoria juspositivista com suas características de imperativismo.

ROBERTO DE AGUIAR, ${ }^{2}$ partindo do pressuposto de uma sociedade hipotética qualquer, trabalha a idéia de que nessa sociedade as diferentes valorações que seus membros dão a determinadas atividades criam uma divisão de trabalho em nível vertical e os membros dos grupos situados nos graus mais altos da cadeia produtiva acabam detendo o poder de ditar

1 BOBBIO, Norberto. O positivismo jurídico. Lições de filosofia do direito. São Paulo: Ícone, 1995, p. 38.

2 In Direito, poder e opressão. 3. ed. São Paulo: Alfa-Omega, 1990, p. 23-24. 
normas aos grupos situados nos níveis inferiores, mantendo, então, o privilégio de legislar. ${ }^{3}$

Essas reflexões reforçam a idéia de que quem legisla é quem detém o poder que, como sabido desde o fim do feudalismo, é a classe com maior poderio econômico, antes a burguesia, hoje os grandes conglomerados econômicos transnacionais.

De outra feita, considerando a explicação do princípio monista dada por LUIZ FERNANDO COELHO para quem: "Por princípio monista entende-se a crença, subjacente à dogmática jurídica, de que o direito é um só, ou seja, a crença na existência de uma ordem jurídica, que é precisamente a de gênese estatal. $\bigcirc$ seu enunciado é a primeira forma de legitimação da ordem social burguesa, e não é muito claro justamente porque constitui um pressuposto, está nas entrelinhas e nos silêncios dos enunciados que formam o saber constituído a partir das normas estatais, e das próprias normas; ainda quando a exigência do rigor científico impõe a concepção lata do direito ligado ao fato das comunidades não estatais, o direito é visto como um e, embora se registrem as várias e diferentes acepções da palavra direito, aquelas que identificam uma realidade outra que não a do direito positivo são consideradas à parte, uma possibilidade excepcional de ampliar o conceito de direito". ${ }^{4}$

Torna-se possível compreender, somando as reflexões de ROBERTO DE AGUIAR com as lições de LUIZ FERNANDO COELHO, que, mais uma vez, em nome da cientificidade do direito e de sua íntima ligação com a classe social no poder, institui-se a acepção de direito com um comando imperativo, só válido se sustentado pela força de coerção emprestada do Estado e advinda do legislador (que não é outro senão a própria classe dominante), ignorando, propositadamente, a existência de inúmeros ordenamentos fora da esfera e do controle estatal (à medida que eles representam um perigo para a ordem vigente).

No Brasil, o exemplo da lei que impera nas favelas, onde os traficantes representam a segurança e proteção e a polícia,

3 Segue a transcrição do trecho aqui referido: "Essa sociedade para se manter necessita de produzir, essa produção origina uma divisão de trabalho, essa divisão de trabalho impregna as outras instituições existentes nessa sociedade. À luz dessas instituições estabelecem-se teias de relações em sentido horizontal e vertical: as relações em nível horizontal são determinadas pelo fato de os indivíduos se situarem no mesmo plano de atribuição ou por terem atribuições semelhantes. As relações em nível vertical são determinadas pelo valor maior ou menor que essa sociedade dá a atribuições diferentes e este valor está relacionado com os modos de produção e apropriação que ela desenvolve. Assim, vão-se formando nessa sociedade grupos humanos em posições paralelas, em posições inferiores ou superiores em relação aos outros. Esses grupos se relacionam dinamicamente na medida em que a sociedade muda, trocando de posições entre si ou simplesmente desaparecendo. O grupo situado nos níveis mais altos das relaçóes verticais detém o poder dominando e controlando os outros grupos e se apropriando daquilo que é mais valioso e útil, daquilo que a sociedade produz. Desse modo, ele passa a deter nas mãos o privilégio de legislar, de ditar normas para si e para os outros que terão de aceitar estas normas, ou porque eles guardam alguma compatibilidade com seus interesses, ou porque tais grupos, ignorando sua própria condição, acreditam serem essas normas as melhores para a sociedade, ou ainda porque neles foi inculcada e internalizada a crença de que são incapazes de governar, ou por último, simplesmente pela força, pela sanção". (grifo nosso)

4 COELHO, Luiz Fernando. Teoria crítica do direito. 2. ed. Porto Alegre: Sergio Antonio Fabris Editor, 1991, p. 266. 
o medo, ${ }^{5}$ demonstra de forma dramática o distanciamento desse dogma com a realidade social.

\section{II - A segunda certeza: a segurança positivista e o mito da neutralidade do juiz}

Após derrubar o mito da neutralidade da lei, cabe agora analisar outros dois fundamentos máximos do positivismo: o mito do juiz neutro e imparcial e o da segurança jurídica advinda do juspositivismo os quais, por sinal, estão intimamente ligados, já que para os positivistas não se pode falar em segurança jurídica quando não se tem certeza das decisões a serem tomadas pelo juiz.

Mas será que há essa certeza mesmo nas sentenças dos juízes mais dogmáticos? Para mostrar que não, será feita uma análise à luz da construção social da realidade e da hermenêutica jurídica.

A noção de juiz neutro e imparcial surge da teoria de que o juiz não pode estar ligado nem objetivamente nem subjetivamente às partes em litígio, sendo que para garantir a imparcialidade das decisões, deve o juiz declarar seu impedimento, incompatibilidade ou suspeição (arts. 134 e 135,
CPC; 252 a 254, CPP), ou seja, o juiz é um órgão que está entre as partes e acima delas.

Consoante explica JACINTO NELSON DA MIRANDA COUTINHO, "durante determinado período da história do pensamento, acreditou-se que era possível ao homem, enquanto sujeito cognoscente, anular-se completamente nas relações de conhecimento. Com isto, procurava-se obter um tipo de saber que não tivesse eivado de qualquer imperfeição humana. Daí o método perfeito para a consecução deste desiderato, proposto pelo empirismo. Para este, 'o método consiste em um conjunto de procedimentos que por si mesmos garantem a cientificidade das teorias elaboradas sobre o real. Como sujeito se limitaria a captar o objeto, essa captação seria tanto mais eficaz e neutra quanto mais rigoroso fosse o método utilizado. Assim, a elaboração científica se limitaria ao cumprimento rigoroso de certas técnicas preestabelecidas, que conteriam o poder quase miraculoso de conferir cientificidade aos conhecimentos elaborados através delas"”. 6

No mesmo sentido, CARLOS ANTONIO DE ALMEIDA MELO ${ }^{7}$ ensina que "cada um tem uma consciência de mundo, que é proporcional ao tamanho de seu conhecimento", sendo que a partir dela, chega-se ao real (aquilo que existe com as

5 Recentemente, os moradores do Rio de Janeiro que freqüentavam o piscinão de Ramos foram proibidos de vestir qualquer peça de roupa vermelha para não fazer alusão ao grupo Comando Vermelho, rival do grupo de traficantes que controla aquela área. Para maior aprofundamento acadêmico dessa questão, remeto o leitor à leitura do texto "Notas sobre a história jurídico-social de Pasárgada" de SOUZA SANTOS, Boaventura de, in SOUTO, Cláudio \& FALCÃO, Joaquim. Sociologia e direito. São Paulo: Pioneira, 1980.

6 In "Princípios gerais do processo penal brasileiro", artigo preparado no âmbito da Comissão de Estudos criada pelo Tribunal de Justiça do Estado do Paraná e Instituto Max Planck, de Freiburg, Alemanha, no Projeto "A Justiça como garantia dos direitos humanos na América Latina". Curitiba, maio de 1998, p. 07.

7 Em aulas proferidas na Faculdade de Direito da UFMT na disciplina de Introdução ao Estudo do Direito. 
nossas valorações) que é o produto da dialética entre materialidade do mundo e o sistema de significação, o qual proporciona a multiplicidade de realidades. Em outras palavras, cada indivíduo tem seu próprio sistema de significação, seus próprios valores (os quais advém desde o ambiente de criação, das situações vividas na escola, de seu credo religioso, de sua raça, etc.), e esses fatores interferem diretamente em sua visão de mundo e também na sua noção de realidade social.

Como conseqüência, ainda de acordo com o citado professor "a compreensão de um texto não decorre apenas da decodificação pura e simples dos itens lingüísticos nele contidos. $\mathrm{Na}$ realidade o leitor deixa aflorar no momento da leitura o seu conhecimento do mundo, suas crenças, suas vivências, os quais conduzem ao estabelecimento de conexões entre os enunciados e os levam a construir o sentido do texto".

\section{Já LUÍS ROBERTO BARROSO usa} argumentos semelhantes para atacar a neutralidade e imparcialidade do juiz em face da hermenêutica: "não será possível libertá-lo de próprio inconsciente, de seus registros mais primitivos. Não há como idealizar um intérprete sem memória e sem desejos. Em sentido pleno não há neutralidade possível (...) é claro que há uma infindável quantidade de casos decididos pelo Judiciário que não mobilizam o juiz em nenhum sentido que não o de burocraticamente cumprir seu dever. Outros tantos casos, porém, envolvem a escolha de va- lores e alternativas possíveis. E aí mesmo quando não atue em nome dos interesses de classe ou estamentais, ainda quando não milite em favor do próprio interesse, o intérprete estará promovendo suas próprias crenças, a sua visão de mundo, o seu censo de justiça". (destaquei)

Aprimorando essa idéia, JACINTO COUTINHO conclui: "o juiz não é mero sujeito passivo nas relações de conhecimento. Como todos os outros seres humanos, também é construtor da realidade em que vivemos, e não mero aplicador de normas, exercendo atividade simplesmente recognitiva. Além do mais, como parece sintomático, ele, ao aplicar a lei, atua sobre a realidade, pelo menos, de duas maneiras: 1) buscando reconstruir a verdade dos fatos no processo, e 2) interpretando as regras jurídicas que serão aplicadas a esse fato ou, em outras palavras, acertando o caso que lhe é posto resolver". (grifei)

Na prática, esse fenômeno é facilmente observável, basta citar, como exemplo, o caso do índio pataxó em que a juíza, numa interpretação complacente com os réus (mauricinhos que, na falta do que fazer, procuravam diversão queimando mendigos), não enxergou o dolo eventual ali caracterizado. Será que, com base na mesma lei, essa decisão não poderia ter sido diferente?

Sustentado por inúmeros exemplos de prática jurídica, AMILTON BUENO DE CARVALHO ${ }^{10}$ vai mais além e chega até

8 BARROSO, Luis Roberto. Interpretação e aplicação da constituição. 2. ed. São Paulo: Saraiva, 1998, p. 258.

9 Op. cit., p. 11.

10 In Direito alternativo em movimento. 2. ed. Niterói: Luam, 1997. 
mesmo a trabalhar a idéia de que a própria localização e o ambiente de trabalho, a hora, o cansaço e até mesmo o humor do juiz no momento de julgar podem interferir na maior ou menor severidade do julgamento.

Outro aspecto a ser lembrando, é o caráter ideológico que se esconde atrás do princípio da neutralidade e imparcialidade do juiz, uma vez que exerce uma função de ocultação dos verdadeiros conflitos existentes na sociedade.

Acerca desse caráter ideológico, LUÍS ROBERTOBARROSO assim se pronuncia: "A idéia de neutralidade do Estado, das leis e de seus intérpretes, divulgada pela doutrina liberal-normativista, toma por base o status quo. Neutra é a decisão ou a atitude que não afeta nem subverte as distribuições de poder e riqueza existentes na sociedade (...) elas são fruto do direito posto. E, freqüentemente, nada têm de justas. A ordem social vigente é fruto de fatalidades, disfunções e mesmo perversidades históricas. Usá-la como referência do que seja neutro é evidentemente indesejável, porque instrumento de perenização de injustiça". ${ }^{11}$ (destaquei)

A saída é dada por JACINTO COUTINHO que proclama que a "democracia - a começar pela processual - exige que os sujeitos se assumam ideologicamente. Por esta razão é que não se exige que o legislador, e de conseqüência o juiz, seja tomado completamente por neutro, mas que procure, à vista dos resultados práticos do direito, assumir um compromisso efeti- vo com as reais aspirações das bases sociais. Exige-se não mais a neutralidade, mas a clara assunção de uma postura ideológica, isto é, que sejam retiradas as máscaras hipócritas dos discursos neutrais, o que começa pelo domínio da dogmática aprendida e construída na base da transdisciplinariedade". ${ }^{12}$

Muito embora, como esse autor reconhece, a neutralidade e imparcialidade possam funcionar como uma meta a ser atingida pelo juiz, ainda que inatingível, à medida que ela constitui "garantia tanto para aquele que exerce a jurisdição, como para aquele que demanda perante ela". ${ }^{13}$

No mesmo sentido, MARÇAL JUSTEN FILHO, ao tentar responder a indagação se é possível a imparcialidade do doutrinador do direito ou ainda se há a possibilidade de um sujeito atenuar a influência de suas convicções políticas mais ferrenhas, assim se manifesta: "Por mais que se pretenda uma resposta positiva, sempre restará a dúvida, relacionada com a própria natureza do ser humano. Não é exagero afirmar que produzir ciência - especialmente, a ciência social - importa, antes de tudo, produzir conhecimento sobre si próprio. Daí a necessidade de o autor esclarecer suas próprias ideologias, deixando claras suas convicções axiológicas e políticas pessoais. É necessário que o leitor conheça o autor da obra que lê para que possa avaliar as opções pessoais realizadas. Somente assim será possível aderir ou rejeitar teses que re-

\section{Op. cit., p. 256-257.}

12 Op. cit., p. 12.

13 Idem. 
tratam certa visão do mundo que informa o autor e se retrata em tomadas de posição fundamentais. Trata-se de evitar o mascaramento de convicções político-ideológicas através de argumentações travestidas de feição lógico-abstrata". ${ }^{14}$ (destaquei)

Analisando essa questão à luz da semiologia do poder, LUIZ ALBERTO WARAT, ${ }^{15}$ verifica que as diferentes significações das palavras da lei atuam como instrumento de controle social, através de inúmeros conceitos vagos ou ambíguos, como mulher honesta (arts. 215, 216 e 219 do CP), justificável confiança (art. 217 do $\mathrm{CP}$ ) e motivo fútil (art. 121 do CP), donde percebe-se que a exaltação do valor segurança é mais um instrumento que tem por principal escopo "legitimar o exercício do poder socialmente dominante, o qual se apresenta como seu legítimo guardião sendo todos os seus atos intrinsecamente justos por serem legais, vale dizer, não arbitrários porque contidos nos marcos das normas gerais. A norma geral adquire, assim, o valor de uma autolimitação apriorística do exercício do poder". ${ }^{16}$

Não é exagero, então, afirmar que o sentido comum teórico dos juristas identificado por WARAT, enquanto topoi interpretativo, constitui o corpus ideologicus que dá segurança e irresponsabilidade aos adeptos do habitus dogmaticus, os quais, sem consciência de seu papel social e das artimanhas dogmáticas, tornam-se meros instru- mentos a favor da reprodução de saberes ins tituídos e da manutenção do status quo.

Assim, em relação à segurança jurídica, e o mito da certeza nas decisões, se for levado em consideração que a lei é comprometida com os interesses dominantes, e o juiz (e todos os intérpretes que operam o direito) não é neutro mas atua (re)construindo seus próprios mundos e valores a cada nova interpretação, gerando decisões díspares num mesmo ordenamento jurídico, é possível crer que não há, absolutamente, segurança ou certeza nas decisões, ainda que emanadas dos juízes mais dogmáticos.

\section{III - A terceira certeza: a hermenêutica de cunho empirista positivista}

Dentro da teoria dogmática clássica, trabalha-se a hermenêutica jurídica num paradigma que aqui será chamado de empirista positivista, à medida que há a profunda crença que o sujeito, ao ler a norma através de diferentes métodos hermenêuticos, pode extrair o seu significado real, ou ainda, de acordo com a corrente a que for filiado, o intérprete poderia extrair da lei a vontade do legislador ou mesmo a vontade da lei, aqui entendida como um ser que ganha vontade própria após ser promulgada.

Esse paradigma hermenêutico encontra-se arraigado no imaginário de gran-

14 JUSTEN FILHO, Marçal. "O Direito das Agências", minuta debatida na disciplina de Direito Econômico no âmbito do Programa de Pós-Graduação em Direito - Mestrado da UFPR, Curitiba: 2002. Inédito, p. 03.

15 In Introdução geral ao direito. Porto Alegre: Sergio Antonio Fabris Editor, 1994.

16 Idem, passim. 
de parte dos juristas brasileiros, não só porque presente como verdade absoluta na maioria dos manuais de introdução ao direito, como também por representar importante método para se atingir a chamada pureza positivista, fechando, desta maneira, o ciclo das certezas que constituem o pilar dessa teoria, pois consagra-se a onipotência do legislador e a neutralidade do juiz com a pureza dos métodos hermenêuticos, os quais proporcionam ao juiz a verdadeira vontade da lei (ou do legislador) no momento de sua aplicação ao caso concreto.

Com efeito, CARLOS MAXIMILIANO, ícone desse modelo de hermenêutica no Brasil, e amplamente aceito pelos juristas e doutrinadores pátrios, enuncia o seu pensamento nas seguintes palavras: "Com a promulgação, a lei adquire vida própria, autonomia relativa; separa-se do legislador; contrapõe-se a ele como um produto novo; dilata e até substitui o conteúdo respectivo sem tocar nas palavras; mostra-se, na prática, mais previdente que seu autor. Consideram-na como disposição mais ou menos imperativa, materializada num texto, a fim de realizar sob um ângulo determinado a harmonia social, objeto supremo do Direito. Logo, ao intérprete incumbe apenas determinar o sentido objetivo do texto, a vis ac potestas legis; deve ele olhar menos para o passado do que para o presente, adaptar a norma à finalidade humana, sem inquirir da vontade inspiradora da elaboração primitiva". ${ }^{17}$
Em contraponto ao que foi exposto no capítulo anterior, crê o citado jurista que é possível ao intérprete despojar-se de suas paixões, crenças, valores e significados de mundo através da autocrítica e da autofiscalização, para que não vicie a interpretação: "Deve o intérprete, acima de tudo, desconfiar de si, pesar bem as razões pró e contra, e verificar, esmeradamente, se é a verdadeira justiça ou se são idéias preconcebidas que o inclinam neste ou naquele sentido. 'Conhece-te a ti mesmo', preceituava o filósofo ateniense. Pode-se repetir o conselho, porém completado assim: 'e desconfia de ti, quando for mister compreender e aplicar o Direito'. Esteja vigilante o magistrado, a fim de não sobrepor, sem o perceber, de boa fé, o seu parecer pessoal à consciência jurídica da coletividade; inspire-se no amor e zelo pela justiça e soerga o espírito até uma atmosfera serena onde o não ofusquem as nuvens das paixões". ${ }^{18}$ (destaquei)

Essa solução não é nova nem suficiente e recai no velho dilema da neutralidade do sujeito das ciências sociais, que é o mito do BARÃO DE MÜNCHHAUSEN, personagem que tenta se salvar da areia movediça puxando os próprios cabelos, conforme assinala MICHEL LÖWY. ${ }^{19}$

Daí infere-se que a tradicional teoria da interpretação, oriunda da hermenêutica de cunho objetivista bettiano exposta na obra de CARLOS

17 MAXIMILIANO, Carlos. Hermenêutica e aplicação do direito. 9. ed. Rio de Janeiro: Forense, 1980, p. 30-31.

18 Idem.

19 LÖWY, Michel. As aventuras de Karl Marx contra o Barão de Münchhausen: marxismo e positivismo na sociologia do conhecimento. 5. ed., rev., trad. de Juarez Guimarães e Suzanne Felicie Léwy, São Paulo: Cortez, 1994. 
MAXIMILIANO, encara a linguagem como um terceiro elemento entre o sujeito cognoscente e o objeto, havendo uma busca de conceitos ensimesmados nas palavras da lei e fazendo com que o sujeito tenha que extrair da norma o seu sentido mais puro possível através da utilização de diversos métodos tais como o gramatical, histórico, teleológico, entre outros.

Analisando a questão, PAUL RICOEUR aduz que a hermenêutica vista sob esse prisma objetivista exerce uma função de distanciamento alienante que recai na seguinte antinomia: "de um lado, dissemos, o distanciamento alienante é a atitude a partir da qual é possível a objetivação das ciências do espírito ou humanas; mas esse distanciamento, que condiciona o estatuto científico das ciências, é, ao mesmo tempo, a degradação que arruína a relação fundamental e primordial que nos faz pertencer e participar da realidade histórica que pretendemos erigir em objeto". ${ }^{20}$

Assim, resta caracterizado que esse modelo hermenêutico é empirista por conceber a possibilidade de um sujeito cognoscente extrair do seu objeto (no caso a norma) o seu verdadeiro sentido através de sua percepção, aqui caracterizado pela leitura, a qual pressupõe a visão. E é positivista por acreditar na norma como um objeto real, dotado de sentido próprio, cuja existência não dependa do sujeito, sendo que esse objeto pode ser representado em sua inteireza pelo conhecimento, bem como sendo possível uma cisão absoluta entre os fatos (contidos na norma) e os valores do sujeito, sendo que essas características constituem, em última análise, pressupostos da teoria positivista. ${ }^{21}$

Outrossim, encarar a linguagem como uma terceira coisa entre o sujeito e o objeto e não como parte de um todo com sentido (sujeito + norma), exclui a responsabilidade do agente de transformar a própria realidade, vez que, apenas observando, contemplando, busca um sentido que já exista e independa de suas crenças.

Ao contrário, tendo o sujeito consciência de que faz parte desse todo e a partir de seu interesse fornece o sentido, sua responsabilidade se cristaliza, pois o resultado da interpretação nada mais é que a soma da concepção de mundo do sujeito com as prescrições do texto normativo do objeto (compreensão), exsurgindo daí um novo sujeito, por isso se diz que a relação ultrapassa o plano sujeito-objeto para se tornar uma viragem lingüística de uma relação sujeito-sujeito.

Nesse diapasão, LÊNIO LUIZ STRECK, ${ }^{22}$ apoiado em HEIDEGGER e em

20 RICOEUR, Paul. Interpretação e ideologias. 4. ed. Rio de Janeiro: Francisco Alves, 1990, p. 43.

21 BOAVENTURA DE SOUSA SANTOS (in Introdução a uma ciência pós-moderna. 3. ed. Rio de Janeiro: Graal, 2000, p. 52) elenca os seguintes pressupostos do positivismo: "a realidade enquanto dotada de exterioridade; o conhecimento enquanto representação do real; a aversão à metafísica e o caráter parasitário da filosofia em relação à ciência; a dualidade entre fatos e valores com a implicação de que o conhecimento empírico é logicamente discrepante do prosseguimento de objetos morais ou da observação de regras éticas; a noção de unidade da ciência, nos termos da qual as ciências sociais e as ciências naturais partilham a mesma fundamentação lógica e até metodológica".

22 In Hermenêutica jurídica e $(m)$ crise: uma exploração hermenêutica da construção do direito. Porto Alegre: Livraria do Advogado, 1999, p. 173-174. 
GADAMER, traz preciosa lição acerca da compreensão: “(...) não é simples dizer que as verdades que fazem parte do universo hermenêutico ou as verdades de um texto que é produzido no universo da hermenêutica são verdades que se resolvem a partir de um universo ingênuo, a partir de uma afirmação ametódica. Somos incapazes de expor todos os pressupostos que estão no universo hermenêutico. Algo sempre escapa. A compreensão, que faz parte do modo de ser no mundo, antecipa qualquer tipo de explicação lógico-semântica, não no sentido temporal, cronológico. Porque estamos no mundo, há uma compreensão que se antecipa a qualquer tipo de explicação. Temos uma estrutura do nosso modo de ser que é a interpretação. Por isto, sempre interpretamos. O horizonte de sentido é nos dado pela compreensão que temos de algo. O ser humano é compreender. Ele só se faz pela compreensão. Ele só se dá pela compreensão. Compreender é um existencial, que é uma categoria pela qual o homem se constitui".

Em outra passagem, desta vez apoiado em HESSE, LÊNIO STRECK ${ }^{23}$ arremata: "O intérprete compreende o conteúdo da norma a partir de uma pré-compreensão, que é a que vai lhe permitir contemplar a norma desde certas expectativas, fazer uma idéia do conjunto e perfilar um primeiro projeto, ainda necessitado de comprovação, correção e revisão através da progressiva aproximação à coi- sa por parte dos projetos em cada caso revisados, com o que a unidade de sentido fica claramente fixada". (destaquei)

Rompe-se, então, com o paradigma da hermenêutica empirista positivista em prol de uma outra abordagem, desta vez filosófica e compreensiva, por alguns denominada hermenêutica filosófica, a qual supera as dicotomias positivistas entre fato/valor, sujeito/objeto, ciência/senso comum.

Nas palavras de CELSO LUIZ LUDWIG, a "onipotência da reflexão, marca registrada da filosofia da consciência moderna, é golpeada duramente pela estrutura objetiva de uma realidade que não permite a cisão completa com um sujeito originária e epistematicamente concebido como consciência reflexiva. Por isso, a reflexão se realiza sempre a partir de uma précompreensão, ineliminável, porque condição de possibilidade de toda compreensão". ${ }^{24}$

É de ressaltar-se que com base nessa hermenêutica filosófica é que alguns estudiosos vêm tentando pensar a ciência e o direito na pós-modernidade, como é o caso de BOAVENTURA DE SOUSA SANTOS. 25

No mesmo sentido, todavia com uma abordagem de maior aplicabilidade prática, CARLOS ANTONIO DE ALMEIDA MELO esboça a seguinte tese: “(...) toda

23 Op. cit., p. 189.

24 LUDWIG, Celso Luiz. Formas da razão - racionalidade jurídica e fundamentação do direito. Curitiba: Universidade Federal do Paraná. Tese de Doutorado aprovada em 1997. Inédito, p. 97-98.

25 In A crítica da razão indolente contra o desperdício da experiência. Para um novo senso comum. A ciência, o direito e a política na transição paradigmática. 2. ed., vol. 1. São Paulo: Cortez, 2000 e Introdução a uma ciência pós-moderna. 3. ed. Rio de Janeiro: Graal, 2000. 
interpretação jurídica é realizada sob a incidência de determinantes e condicionantes que atuam simultaneamente na atividade do intérprete. Determinantes são os fatores relacionados ao próprio intérprete como ideologia, visão de mundo, posição social e demais interesses que direcionam sua atividade de busca de significado das normas jurídicas. Por sua vez, as condicionantes estabelecem o horizonte interpretativo e firmam as balizas da interpretação ou, em outras palavras, condicionam os limites em que a interpretação pode estar contida. As determinantes são insuscetíveis de controle externo, uma vez que configuram fatores aos quais apenas o próprio intérprete tem acesso pleno. Por sua vez o controle das condicionantes pode ser exercido pelo sistema jurídico que se encarrega de obstruir o trânsito das interpretações que ponham em risco sua coerência e integridade. Neste sentido, as interpretações discordantes prosperam apenas na doutrina, embora, por isto, não deixem de ter relevância para o sistema, funcionando como possibilidades de mudança interpretativa. (...) uma norma pode oferecer um horizonte interpretativo extremamente estreito, ensejando uma interpretação especificadora ou declaratória (quando fixa um prazo ou estabelece uma certa idade para a prática de um ato, por exemplo) ou, ao contrário, possibilitar um significativo alargamento ou fechamento, maior ou menor, da interpretação (por exemplo, quando contém conceitos indeterminados), possibilitando uma interpretação extensiva ou restritiva". ${ }^{26}$

Por sua vez, e com muita propriedade, IVAN GUÉRIOS CURY assevera: "A chamada 'ultrapassagem da dimensão dogmática', todavia, significa mais a possibilidade de dar um enfoque retrospectivo à própria dimensão, antes que tentar pura e simplesmente, eliminá-la. Esse enfoque, a meu ver, se dá no plano efetivo do direito, que é o da decidibilidade, porque o prisma do jurista é diferente, neste particular, do prisma do literato, ou do historiador, à medida que deve passar da compreensão à decisão, ou pelo menos, às condições de decidibilidade. Desta forma, vejo na hermenêutica a conjunção de seu aspecto crítico e revelação dos aludidos pressupostos ideológicos com seu aspecto funcional de investigar o texto - no contexto - para viabilizar a decisão, ou, permitir que se estabeleçam condições de decidibilidade, de modo a neutralizar os conflitos sociais revelados pela crítica". ${ }^{27}$ (destaquei)

Supera-se, assim, a terceira certeza positivista, florescendo as possibilidades de se pensar uma outra postura perante o arcabouço normativo que, longe do cientificismo e dogmatismo, passe a se preocupar também com os conflitos sociais subjacentes ao conflito jurídico. ${ }^{28}$

26 Em artigo intitulado "A argüição de descumprimento de preceito fundamental e o horizonte interpretativo da Constituição" e apresentado no XXVII Congresso Nacional dos Procuradores de Estado, em Vitória/ES, em outubro de 2001.

27 CURY, Ivan Guérios. Dilemas do direito penal - reflexão a partir da hermenêutica do sistema. Curitiba: Universidade Federal do Paraná. Tese de Doutorado aprovada em 1999. Inédito, p. 71.

28 LÊNIO STRECK no artigo intitulado "A revelação das obviedades do sentido comum e o sentido (in)comum das obviedades reveladas" (in OLIVEIRA JÚNIOR, José Alcebíades de. (org.) O poder das metáforas: homenagem aos 35 anos de docência de Luiz Alberto Warat. Porto Alegre: Livraria do Advogado, 1998) bem demonstra a distância da realidade dos juristas que atuam no 


\section{IV - 0 rompimento com as idéias positivistas através da busca da instrumentalidade das normas}

Rasgado o véu que esconde a maligna face do positivismo jurídico, ou melhor, a maligna falta de face que faz com que o positivismo legitime qualquer ideologia que interesse a quem detenha o poder, até mesmo a nazista, surge a busca da instrumentalidade das normas jurídicas muito mais como um postura do operador do direito perante o ordenamento jurídico e todo arcabouço normativo - postura esta que rompa com o dogmatismo e com os postulados conservadores da doutrina aqui estudada - do que como uma teoria para o direito ou uma solução mágica para todos os problemas do universo jurídico.

Com efeito, é possível encarar a norma não mais como um dogma, mas sim como um instrumento a favor da justiça e da prestação jurídica a quem dela necessite e para isso é preciso pensar o direito a partir de alguns enunciados básicos:

a) não existe segurança jurídica à medida que o direito é aplicado e trabalhado por pessoas as quais, acima de tudo, são humanas e ao interpretar a norma, reconstroem com ela sua visão de mundo, o que também atinge a imparcialidade e a neutralidade dos julgadores;

b) diferenciar dogmatismo de dogmática, pois enquanto o primeiro é o apego exacerbado e acrítico à letra legal, a segunda é todo o instrumental disponível aos operadores do direito para que possam peticionar, emitir pareceres, julgar, tais como a lei, a doutrina, a jurisprudência, etc.;

c) ousar e ter criatividade, até mesmo extrapolando os limites da legalidade rasteira, vez que o sistema jurídico constitucional permite certa margem de discricionariedade (horizonte interpretativo de sentido) ao instituir a Constituição como o topo da hierarquia normativa e hermenêutica, possibilitando que se aplique e se interprete o direito levando-se em consideração os objetivos e princípios expostos no texto da Carta Magna;

d) privilegiar a justiça em detrimento da segurança na solução de conflitos normativos ou no caso da escolha entre interpretações díspares da mesma norma, porém igualmente válidas;

e) fugir da síndrome de Abdula ${ }^{29}$ e romper com o senso comum teórico dos

âmbito dogmático do senso comum teórico dos juristas: "(...) pouco importa ao jurista, inserido no sentido comum teórico, o conteúdo das relações sociais. Pouco importa a teratologia resultante do paradoxo que é a imposição de uma pena mais branda a quem estupra uma criança em comparação com aquele que estupra uma mulher adulta (...) (referindo-se ao conflito de normas entre a Lei $n^{\circ} 8.069$ e a Lei no 8.072) (...) O que importa é fazer uma boa hermenêutica; o importante é resolver com competência dogmática, neutramente, as antinomias do sistema (....) Vale lembrar nesse contexto o dizer de RUSSO, para que qualquer estudante saiba que a verdade, em lógica formal, se adquire ao preço de renunciar ao conhecimento de mundo". (destaquei)

29 LÊNIO STRECK, (Hermenêutica jurídica e(m) crise, op. cit., p. 206-207), explica essa síndrome e suas conseqüências a partir de um conto de ÍTALO CALVINO: "Pela estória, Alá ditava o Corão para Maomé, que, por sua vez, ditava para Abdula, o escrivão. Em determinado momento, Maomé deixou uma frase interrompida. Instintivamente, o escrivão Abdula sugeriu-lhe a conclusão. Distraído, Maomé aceitou como palavra divina o que dissera Abdula. Este fato escandalizou o escrivão que abandonou o profeta 
juristas, que faz com que os operadores sempre recorram às interpretações de grandes doutrinadores ou ainda dos tribunais, os quais seriam os únicos aptos a dizer o direito, gerando uma nova forma de divisão do trabalho jurídico;

f) não apenas reproduzir velhas fórmulas e ensinamentos pois em cada caso há variantes compostas pelo momento histórico, pelas circunstâncias em que ocorreu e, principalmente, pelas suas conseqüências sociais.

Enfim, irretocável é a lição de AMILTON BUENO DE CARVALHO em relação aos óbices de se tomar uma postura mais crítica e progressista frente a dogmática jurídica: "é terrível a dificuldade em se trabalhar teoricamente. No momento da abstração tudo parece sem sentido. $O$ operador jurídico necessita ver para compreender (a tônica é: por favor, dêem-me um exemplo!). Daí a cópia (a repetição) parece inevitável (e com a massificação do computador chega-se ao limite copiativo insuportável: iniciais e sentenças de conteúdos desconexo, cansativo, acrítico passam a ser algo inevitável no espaço forense). Pensar? Criar? Jamais, pois não somos treinados para tanto. ROBERTO GOMES (Crítica da razão tupiniquim, 9. ed. Criar, p. 91), em sempre atual estudo, bem apanha a questão: 'Eis o convite que nos aterroriza e que nos põe nos limites de nossas certezas: pensar por conta própria. Me contaram ou li (ou inventei) que segundo os chineses 'pensar dói'. Dói. É um risco a assumir. Exige colocar tudo em jogo. É conduzir-se aos limites a despeito da insegurança. É neste momento que o chão nos falta - e preferimos a burra paz dos que não sabem. De fato, pensar dói. Mas é a única coisa que nos resta."' 30 (destaquei)

\section{Referências bibliográficas}

AGUIAR, Roberto Armando Ramos de. Direito, poder e opressão. 3. ed. São Paulo: Alfa-Omega, 1990.

ALMEIDA MELO, Carlos Antonio de. "A argüição de preceito fundamental e o horizonte interpretativo da Constituição", artigo apresentado no XXVII Congresso Nacional dos Procuradores de Estado, em Vitória/ES, em outubro de 2001.

BARROSO, Luís Roberto. Interpretação e aplicação da constituição. 2. ed. São Paulo: Saraiva, 1998.

BOBBIO, Norberto. O positivismo jurídico: lições de filosofia do direito, comp. por Nello Morra; trad. de Marcio Pugliese. São Paulo: Ícone, 1995.

CARVALHO, Amilton Bueno de. Direito alternativo em movimento. 2. ed. Niterói: Luam, 1997.

. Teoria e prática do direito alternativo. Porto Alegre: Síntese, 1998.

COELHO, Luiz Fernando. Teoria crítica do direito. 2. ed. Porto Alegre: Sergio Antonio Fabris Editor, 1991.

e perdeu a fé. Abdula não era digno de falar em nome de Alá". Não há exagero em fazer uma analogia desta estória com o que ocorre no cotidiano das práticas jurídicas. Assim como o personagem Abdula não tinha consciência do seu poder (e de seu papel), os operadores jurídicos também não conhecem as suas potencialidades hermenêuticas de produção do sentido. Em sua maioria, prisioneiros das armadilhas e dos grilhões engendrados pelo campo jurídico sofrem dessa síndrome de Abdula. Consideram que sua missão e seu labor é o de apenas reproduzir os sentidos previamente dados/adjucados/atribuídos por aqueles que têm o skeptron, é dizer a fala autorizada! Não se consideram dignos-de-dizer-o-verbo. Perderam a fé em si mesmos. Como órfãos científicos, esperam que o processo hermenêutico Ihes aponte o caminho-da-verdade, ou seja, a correta interpretação da lei! Enfim, esperam a fala-falada, a revelação da verdade! (destaquei)

30 CARVALHO, Amilton Bueno de. Teoria e prática do direito alternativo. Porto Alegre: Síntese, 1998, p. 12. 
CURY, Ivan Guérios. Dilemas do direito penal - reflexão a partir da hermenêutica do sistema. Curitiba: Universidade Federal do Paraná. Tese de Doutorado aprovada em 1999. Inédito.

JUSTEN FILHO, Marçal. "O Direito das Agências", minuta debatida na disciplina de Direito Econômico no âmbito do Programa de Pós-Graduação em Direito - Mestrado da UFPR, Curitiba: 2002. Inédito.

LÖWY, Michel. As aventuras de Karl Marx contra o Barão de Münchhausen: marxismo e positivismo na sociologia do conhecimento. 5. ed., rev., trad. de Juarez Guimarães e Suzanne Felicie Léwy. São Paulo: Cortez, 1994.

LUDWIG, Celso Luiz. Formas da razão-racionalidade jurídica e fundamentação do direito. Curitiba: Universidade Federal do Paraná. Tese de Doutorado aprovada em 1997. Inédito.

MAXIMILIANO, Carlos. Hermenêutica e aplicação do direito. 6. ed. Rio de Janeiro: Forense, 1980.

MIRANDA COUTINHO, Jacinto Nelson de. "O papel do pensamento economicista no direito criminal de hoje", texto especialmente preparado para o VII Encontro Internacional de Direito da América do Sul, realizado em Florianópolis/ SC, de 06 a 08 de maio de 1998.

. "Princípios gerais do processo penal brasileiro", artigo preparado no âmbito da Comis- são de Estudos criada pelo Tribunal de Justiça do Estado do Paraná e Instituto Max Planck, de Freiburg, Alemanha, no Projeto "A Justiça como garantia dos direitos humanos na América Latina”, Curitiba, maio de 1998.

OLIVEIRA JÚNIOR, José Alcebíades de (org.). O poder das metáforas: homenagem ao 35 anos de docência de Luis Alberto Warat. Porto Alegre: Livraria do Advogado Editora, 1998.

RICOEUR, Paul. Interpretação e ideologias. 4. ed. Rio de Janeiro: Francisco Alves, 1990.

SOUSA SANTOS, Boaventura. O discurso e o poder: ensaio sobre a sociologia da retórica jurídica. Porto Alegre: Sergio Antonio Fabris Editor, 1988.

. A crítica da razão indolente contra o desperdício da experiência. Para um novo senso comum. A ciência, o direito e a política na transição paradigmática. 2. ed., vol. 1. São Paulo: Cortez, 2000.

. Introdução a uma ciência pós-moderna. 3. ed. Rio de Janeiro: Graal, 2000.

STRECK, Lênio Luiz. Hermenêutica jurídica e $(m)$ crise: uma exploração hermenêutica da construção do direito. Porto Alegre: Livraria do Advogado, 1999.

WARAT, Luis Alberto. Introdução geral ao direito. Porto Alegre: Sergio Antonio Fabris Editor, 1994. 